\title{
Adaptation of cassava agribusiness systems during the Covid-19 pandemic (case in Pasar Pedati Village, Bengkulu Province)
}

\author{
Wilda Mikasari, Emlan Fauzi, Taufik Hidayat \\ Bengkulu Assessment Institute for Agricultural Technology, Jl. Irian KM 6.5 Kel. Semarang, \\ Bengkulu, Indonesia
}

\begin{abstract}
The cassava agribusiness system involves farmers from upstream to downstream. This study aims to determine the effect of the covid-19 pandemic on the cassava agribusiness system and the adaptation of farmers. The research was conducted from March to April 2021 in Pasar Pedati Village, Pondok Kelapa Subdistrict, which is the center of cassava production in Bengkulu Tengah Regency. Data has collected the conditions of cassava agribusiness system and farmers' adaptation in pandemic through in-depth interviews involved seven key informants, besides observation and secondary data collections. Data analyzed descriptively. The results showed that the pandemic does not affect the entire cassava agribusiness, disrupted only the marketing and processing subsystem, because: (1) cassava cultivation is a part-time business that low costs input; (2) farmers adjusting the production capacity of cassava chips by the demands of traders; (3) farmers still selling cassava harvests in fresh form even at low prices and making dried cassava (gaplek) to extend the shelf life of cassava. Farmers continued to cultivate cassava in the hope that the pandemic will end at any time in addition to anticipating the fulfilled of family food needs to replace rice as a staple food.
\end{abstract}

\section{Introduction}

Agricultural commodity agribusiness development requires linkages between agribusiness subsystems from upstream to downstream. This linkage is formed in an agribusiness system which is the entire process of production, storage, processing, and distribution of commodities [1]. Therefore, in simple terms, the agribusiness system consists of input, production, processing, and marketing subsystems, as well as supporting subsystems that facilitate commodity production activities to marketing to consumers [2-5].

Cassava (Manihot utilissima) is an important agricultural commodity for farmers due to its various functions, among others, to substitute a staple food source from rice [6-8] to support community food security. In addition, more than 20 traditional culinary products have been produced from cassava such as cassava chips and cassava crunchy to increase the added value of cassava products and farmers' income [9].

\footnotetext{
*Corresponding author: wilda.mikasari@yahoo.com
} 
Various disturbances in the cassava agribusiness system cause problems for farmers, especially price uncertainty [10], which disrupts the sustainability of the cassava agribusiness system and reduces farmers' bargaining power. Various ways are suggested to anticipate disturbances in the marketing subsystem, including through the formation of clusters that connect farmer institutions and markets [11], strengthening the processing subsystem by diversifying cassava products to increase farmers' bargaining power [9, 12 , 13], facilitation financing [14, 15], and government program support [16].

The bargaining power of farmers is not only related to the relationship between farmers as producers and traders in an asymmetric agribusiness system that is detrimental to farmers. Unexpected factors that harm both parties include the situation outside the agribusiness system. The covid-19 pandemic that occurred in the past year has disrupted the cassava agribusiness system. An example is the cassava production center in Pasar Pedati Village, Pondok Kelapa Subdistrict, Central Bengkulu Regency. This area is a producer of cassava chips and various other processed cassava products which are a source of income for farmers $[12,17]$. How the adaptation of cassava farmers in the agribusiness system facing a pandemic is interesting to discuss. Therefore, this study aims to determine the effect of the covid-19 pandemic on the cassava agribusiness system and the adaptation of farmers to deal with it in Pasar Pedati Village.

\section{Research methods}

The research was conducted in Pasar Pedati Village, Pondok Kelapa District, Central Bengkulu Regency from March to April 2021. It was conducted with a qualitative approach that emphasizes processes and meanings that are not strictly measured in terms of quantity, intensity, and frequency [18].The data was collected through in-depth interviews involving 7 key informantsconsisting of the head of the farmer group, village officials, the head of the women's farmer group, the cassava processing group, and the traders.In addition, secondary data and field observations were also collected to confirm the interview data.

The data collected includes the characteristics of the research location, the performance of the agribusiness system (input, production, processing, and marketing subsystems) before and during the pandemic, and the adaptation of farmers to it. Data were analysed descriptively using an interactive model [19]. In this model, data collection, reduction, presentation, drawing conclusion, and verification forming a cycle (Fig. 1).

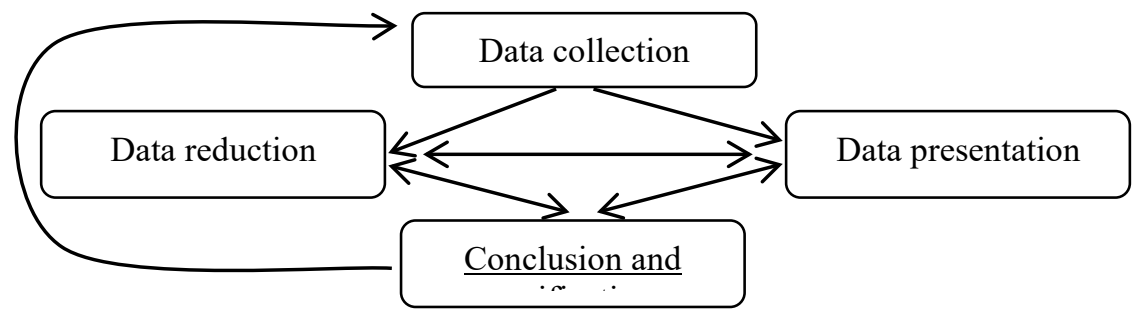

Fig. 1. Interactive model analysis scheme [19]

\section{Results and Discussion}

\subsection{Characteristics of location and cassava farmers}

Pondok Kelapa subdistrict is one of 11 subdistricts in Bengkulu Tengah Regency. The subdistrict is a center for cassava production. Cassava harvest in Central Bengkulu Regency 
covers an area of 176 hectares, 90 hectares or 51.14 percent of which are in Pondok Kelapa subdistrict [20].

Pasar Pedati Village is one of 17 villages in Pondok Kelapa Subdistrict which is located on the west coast of Sumatra Island bordering the Indian Ocean. The area of Pasar Pedati Village is 950 hectares, it is estimated that 65 hectares of which are cassava planting areas. The population in Pasar Pedati Village is 4,377 people, consisting of 1,276 families spread over 3 hamlets or 14 neighbourhood associations. Pasar Pedati Village is about $11 \mathrm{~km}$ from Bengkulu City (the capital of Bengkulu Province) and can be reached from the city about 20 minutes away by a 4-wheeled vehicle. As a buffer zone for the city, most of the heads of families (about 65 percent) in Pasar Pedati Village work in the informal sector such as laborers, artisans, or employees in Bengkulu City. Its position close to Bengkulu City as a potential market greatly supports the development of cassava agribusiness (Fig. 2).

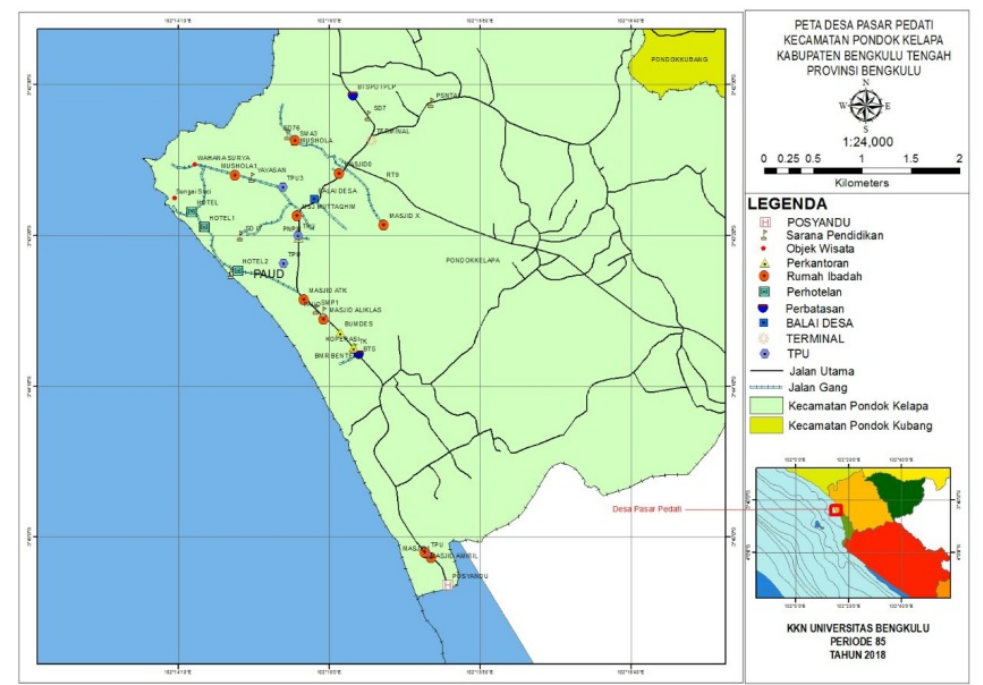

Fig. 2. Map of Pasar Pedati Village (source: Profil Desa Pasar Pedati, 2018)

Cassava began to be cultivated by farmers in Pasar Pedati in the early 2000s. The development of cassava agribusiness in this village is indicated by the large number of farmer groups working on this commodity. Currently, 78 farmers are members of five farmer groups who cultivate cassava on an estimated area of 65 hectares and one of the women farmers group who processes cassava products (Table 1).

Table 1. Farmer groups that cultivating cassava in Pasar Pedati Village.

\begin{tabular}{|c|l|c|c|}
\hline No & \multicolumn{1}{|c|}{ Farmer group } & $\begin{array}{c}\text { Number of members } \\
\text { (people)* }\end{array}$ & Estimated land area (ha)** $^{* *}$ \\
\hline 1. & Jaya Mandiri & 13 & 6 \\
\hline 2. & Berkat Bersama & 14 & 9 \\
\hline 3. & Sungai Suci & 20 & 35 \\
\hline 4. & Serumpun & 11 & 7 \\
\hline 5. & Karya Mulia & 20 & 8 \\
\hline 6. & $\begin{array}{l}\text { Bina Tani Women } \\
\text { Farmer Group }\end{array}$ & 20 & - \\
\hline & Total & 78 & 65 \\
\hline
\end{tabular}

Source: * Simluhtan (https://app2.pertanian.go.id/simluh2014/gst/welcome.php)

** interviews with various informants 


\subsection{Cassava agribusiness system performance before the pandemic}

The cassava agribusiness system in Pasar Pedati Village was created due to the support of the upstream to downstream subsystems, namely the input subsystem, production subsystem, processing subsystem, and marketing subsystem.Cassava began to be planted by farmers in the early 2000 s to be sold in fresh form. The product processing subsystem was formed in 2005 since a buyer from Bengkulu City bought cassava chips. The performance of the cassava agribusiness system before the pandemic is described as follows.

\subsubsection{Input subsystem}

Input in cassava cultivation is a production factor available in cultivation activities. The farm inputs consist of land, plant seeds, production facilities, and labor. The land used to cultivate cassava is not land owned by farmers but controlled by capital owners who live in various cities such as Bengkulu, Palembang, and even Jakarta. These lands were beginning owned by soldiers of the Indonesian National Army (TNI) during the New Order era and sold in the 1970 s.

In the 1980s, landowners began to bring in ethnic Javanese workers to plant coconuts in Hamlet 1 Pasar Pedati Village. The workers are paid Rp. 15,000 per month and given necessities, made a hut for temporary residence, and can use the existing land for seasonal crop farming activities with an overlapping (tumpeng garap) system. If it is needed by the landowners, for example, to sell or create an oil palm plantation, then the land will be returned by the farmer to the landowners. At this time, of the approximately 150 hectares of tumpeng garap land located in Hamlet 1, Pasar Pedati Village, only 65 hectares are still being used by farmers for cassava cultivation. The rest have become oil palm plantations, tourism and public facilities, and residential areas. With this tumpeng garap system, farmers do not need money to rent land.

Cassava seeds are local varieties cultivated for consumption purposes and as raw material for product processing. There are 5 varieties of cassava, namely Arema, Mentega, Utri Genjah, Lanting, and Melati. Most of the farmers cultivate Melati variety to be used as processed products such as cassava chips, modified cassava flour (mocaf), cassava crunchy, fermented cassava, and cassava crunchy. Meanwhile, other varieties are cultivated for sale in fresh form. Cassava stem cuttings are prepared by the farmer himself from the previous cropping. about $1 / 3$ part at the base and $1 / 3$ part at the end of the stem should be removed. According to the informants, the base and the end of the stem were not used for cassava seeds because the tubers were not optimal.

Cassava cultivation in Pasar Pedati Village requires a relatively small cost, which is around 5 million rupiahs per hectare. Farmers use herbicides to control weeds especially reeds (imperata cylindrica). The land is ploughed with 4-wheel tractors rented from farmer groups. Cassava cultivation is carried out by utilizing labour from within the family, hire farm laborers, or by working together in farmer groups using the sambatan system (labour exchange).

\subsubsection{Production subsystem}

Cultivation activities begin with the preparation of planting land. The land was plowed using a 4-wheeled tractor (zonder). The farmer prepares the plant seeds vegetatively with stem cuttings.Stem cuttings are cut about $25 \mathrm{~cm}$ and planted $5 \mathrm{~cm}$ deep with a rather tight spacing of $70 \times 80 \mathrm{~cm}$ in monoculture. This spacing is intended to prevent plants from breaking due to strong winds from the Indian Ocean.Weeding is done at the age of 2-3 
months after planting.At the same time, the hoarding is done about $15 \mathrm{~cm}$ at the base of the cassava plant to form a moundin the row of plants, and reducing branches.

Harvest age varies according to the variety planted. Melati varieties are harvested at 6 months after planting, while other varieties are harvested at 8 months after planting. In one plant can be harvested $10-15 \mathrm{~kg}$ of cassava tubers. Harvesting is carried out in stages over 1-2 months according to farmer needs and market demand. Harvesting is also often carried out by collector traders on a wholesale system according to the price agreed upon between farmer and trader. Most of the yields are sold in fresh form.

The cropping pattern applied by farmers is cassava monoculture. If the cassava production is not optimal, farmers rotate the cassava with other seasonal crops such as peanuts or corn. When planting the two plants, farmers apply more intensive cultivation techniques to optimize production by applying fertilization. After harvesting, the land will be replanted with cassava.

The cropping pattern applied by farmers is cassava monoculture. Farmers rotate cassava with other seasonal crops such as upland rice, corn, or green beans after planting cassava three times. The straw at harvest is left to rot before the land is plowed back to plant cassava.

\subsubsection{Processing subsystem}

Most of the cassava yields are sold in fresh form at a price of around Rp. 1,500-2,000 per kg. Farmers, especially in the Bina Tani women farmer group, are trying to increase the added value of cassava by processing fresh products into various processed products. These processed products are cassava chips, cassava crunchy, mocaf, and cassava crispy crackers. Fig. 3 shows the utilization of cassava yields in Pasar Pedati Village.

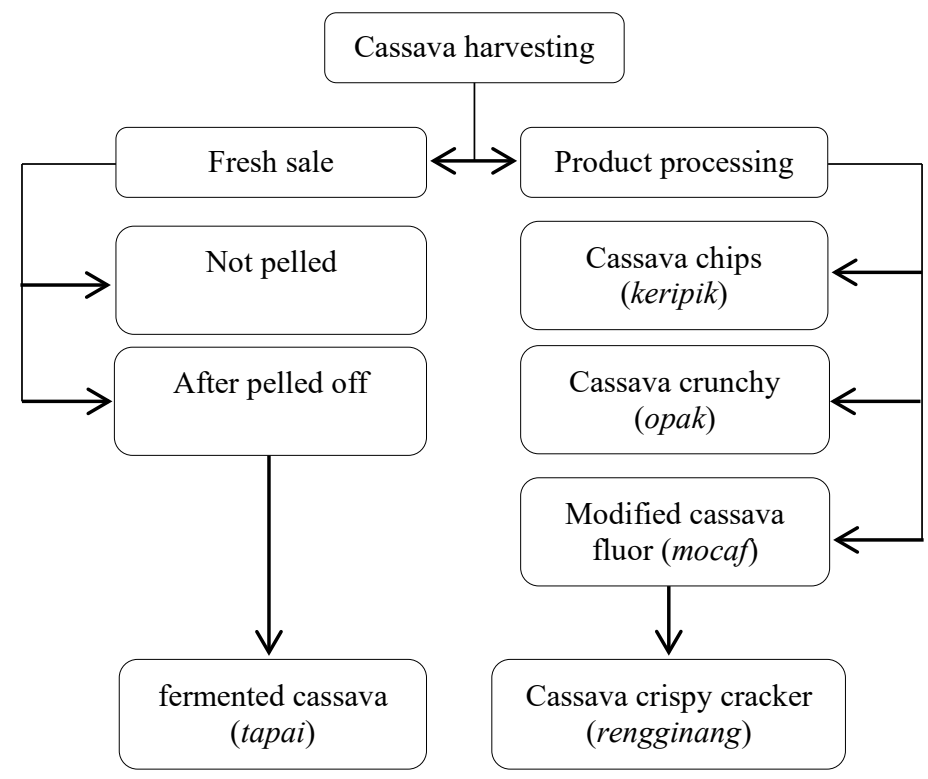

Fig. 3. Utilization of cassava yields (source: interview data)

Cassava chips are the main processed product in Pasar Pedati Village. The making of cassava chips is carried out every day by involving the workforce in the family. In one day, $45 \mathrm{~kg}$ of chips can be produced with $100 \mathrm{~kg}$ of fresh cassava as raw material. Cassava which will be processed into chips is peeled and washed first, then boiled in a pan for about 
20 minutes until half cooked. Furthermore, the cassava is soaked for 12 hours, washed again, and boiled until cooked, then drained and cooled. The cooked cassava is thinly sliced and dried in the sun for 1 day on plastic or tarpaulin racks. The continuity of the production of cassava chips is very dependent on weather conditions because it is related to a drying process. Cassava chips are sold for Rp. $10,000 / \mathrm{kg}$ and can get a net income from processing cassava chips around Rp. 5,000/kg.

Cassava crunchy is a processed product that is made in relatively small quantities. Farmer's peel, wash and grate cassava, mix it with spices before printing it in a round shape on a thin plastic container. Cassava crunchy molds with a diameter of about $30 \mathrm{~cm}$ are then arranged in layers to be steamed in a pan until cooked, before drying for about 5 hours. Farmers can produce 100 cassava crunchy per day which traders buy for Rp. 400 per piece. The net income obtained by this opaque processor is around Rp. 30,000/day from $10 \mathrm{~kg}$ of fresh cassava raw material.

Mocaf is fermented cassava flour. The manufacturing process uses a mocaf flour processing machine. Fresh cassava is peeled and washed, then chopped by machine. The chopped results are washed again before fermentation for 12 hours. After completion of fermentation, the chopped cassava is washed again and dried in the sun for 2-3 days on plastic or tarpaulin racks until the water content is about 12 percent. After drying, the chopped cassava is then pressed and ground into flour using a machine and packed in a plastic container. Mocaf is sold for Rp. $10,000 / \mathrm{kg}$. The net profit of mocaf production is around Rp. 3,000/kg. Mocaf is only produced based on orders from consumers or for culinary ingredients such as cassava crispy crackers.

Cassava crispy cracker is a derivative product of mocaf flour which is produced by mixing it with sago flour and adding salt and flavorings to taste. The crackers are molded in a round shape using a plastic filter, before steaming for about 20 minutes, then drying in the sun for about 4 hours. The value of cassava crispy cracker processing is around $\mathrm{Rp}$. $6,000 / \mathrm{kg}$ with a selling price of Rp. $25,000 / \mathrm{kg}$.

\subsubsection{Marketing subsystem}

The marketing subsystem is an important downstream subsystem that forms the sustainability of the cassava agribusiness system in Pasar Pedati Village. The marketing of cassava is carried out by farmers in fresh or processed form to collector traders and processors. Collector traders will then sell cassava products to retailers before the products are purchased by consumers. Meanwhile, cassava processors will process the cassava product before it is sold to collectors, retailers, or consumers. Cassava marketing channels are presented in Fig. 4.

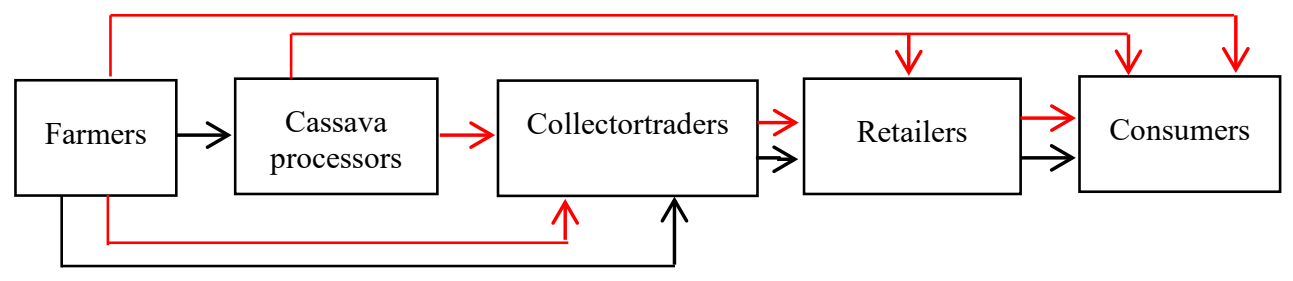

Fig. 4.Marketing channels of cassava products from Pasar Pedati Village Notes:

$\rightarrow$ Sales of processed products

Sales of fresh product

Fig. 4 shows that cassava processors have a strategic role in driving the marketing network for cassava products from Pasar Pedati Village. This is because they relate to all 
market participants, from farmers to consumers in the marketing channels. The role of farmers is also very important because they can be product processors, as well as retailers. Collector traders play a more important role in distributing cassava products on a large scale to retailers who will then sell fresh products or processed cassava products to consumers.

The marketing of processed cassava products to collector traders is done directly by farmers to traders who come to Pasar Pedati looking for cassava products or by subscribing which is done through previous orders. According to several informants, seven collector traders usually looking for cassava products at the Pasar Pedati, three of whom work together with farmers through a subscription system.

\subsection{Farmer adaptation in cassava agribusiness system during the pandemic}

The covid-19 pandemic situation experienced by the world since early 2020 has also affected the cassava agribusiness system in Pasar Pedati Village. The marketing subsystem has been severely disrupting due to the decreasing market for fresh cassava and its processed products. Informants stated that the price of cassava at the time of the study was only Rp. 500/kg and orders for the main processed product, namely cassava chips, decreased by 75 percent. Three traders collect cassava chips, who market their products only in Bengkulu City.

The decline in demand for cassava chips caused several things related to the government's policy on large-scale social restrictions implemented to prevent crowds of people controlled the spread of the covid-19. The decrease in the market for cassava chips is due to: (1) the implementation of learning from home for students during the pandemic; (2) the prohibition of the implementation of wedding parties that reduce catering business activities; (3) implementation of strict health protocols for government agencies through a work from home policy that reduces restaurant activities.

The reduced market demand for cassava and its processed products has caused farmers and cassava processors to experience difficulties in marketing their products, especially cassava chips that are preferred by consumers [21]. Adaptations made by farmers in response to disturbances in the marketing and processing subsystem of cassava products, namely: (1) farmers tend to market their cassava harvest in fresh form even though the price is much lower, (2) make dried cassava (gaplek) to extend the shelf life of cassava harvest, and (3) producing cassava chips only based on orders from collector traders.

Disruption of the cassava agribusiness system in Pasar Pedati Village occurs only in the downstream subsystem (product processing and marketing) without damaging the upstream subsystem (input and production) briefly described in Table 2.

Table 2. Effect of the pandemic on cassava agribusiness system and farmer adaptation.

\begin{tabular}{|c|l|l|l|}
\hline No & Agribusiness subsystem & \multicolumn{1}{|c|}{ Effect of pandemic } & \multicolumn{1}{|c|}{ Farmers adaptation } \\
\hline 1. & Input subsystem & - & - \\
\hline 2. & Production subsystem & - & - \\
\hline 3. & Processingsubsystem & $\begin{array}{l}\text { Reduction of cassava chips } \\
\text { production }\end{array}$ & $\begin{array}{l}\text { Limiting the production of } \\
\text { cassava chips according to } \\
\text { customer orders }\end{array}$ \\
\hline 4. & Marketing subsystem & $\begin{array}{l}\text { Farmers have difficulty } \\
\text { marketing cassava products }\end{array}$ & $\begin{array}{l}\text { Making gaplek to extend } \\
\text { the shelf life of cassava } \\
\text { harvest }\end{array}$ \\
\hline
\end{tabular}

Source: interviews with various informants 
Table 2 shows that the covid-19 pandemic has not disrupted the entire agribusiness system. The persistence of the cassava agribusiness system in this pandemic is mainly because cassava farming is only a source of additional income for farmer households, most of whom as informal workers in Bengkulu City. Cassava farming chose by the farmers as a side activity because the maintenance process is easy and does not require intensive attention [22].

Farmers continue to cultivate cassava because of the hope that the pandemic will soon pass so that the marketing of cassava and its processed products will return to normal. The farmers who continue to cultivate food crops have only brought a little anxiety in the pandemic. They hope that crop production will continue after the pandemic [23].

In addition, the freshly harvested cassava can still be sold even at a relatively cheap price during the pandemic, besides being processed by farmers into gaplek to extend shelf life. Cassava can be used as a staple food substitute for rice which ensures family food security. Food diversification required in the program of food security long time strategies [24].

\section{Conclusions}

Cassava farmers in Pasar Pedati Village were able to adapt to the agribusiness system during the pandemic. The upstream subsystem (input and production) is not disturbed even though there are disturbances in the downstream subsystem (processing and marketing). The adaptation of farmers in cassava agribusiness during the pandemic is by making dried cassava (gaplek) to extend the shelf life of cassava harvests and reduce the production of chips according to customer orders.

\section{References}

1. D. Zylbersztajn, Agribusiness systems analysis: origin, evolution and research perspectives, Revista de Administração. 52 (2017).

2. V.P. Gandhi, Ind. Jn. of Agri. Econ. 69, 1 (2014).

3. N. Harli, Irham, Jamhari, HABITAT. 29, 2 (2018).

4. R.P. King, M. Boehlje, M.L. Cook, S.T. Sonka,J.Agr.Econ. 92, 2 (2010).

5. I.S. Roidah, D. Koestiono, B. Setiawan, R. Anindita, Agricultural Socio-Economics Journal. 19, 3 (2019).

6. D. Rahmawati, F.E. Chandra, M. Pratiwi, The developmentof rice substitute product using fermented cassava (oyek) enriched with isolated soy protein, in Proceeding of IOP Conf. Series: Earth and Environmental Science 292, 012057 (2019).

7. R.W. Arief, E. Novitasari, R. Asnawi, Planta Tropika. 6, 2 (2018).

8. H. Saediman, S. Aisa, M. Zani, M.A. Limi, W. Yusria, Journal of Agricultural Extension. 23, 1 (2019).

9. Suharko, B. Hudayana, Sodality. 8, 2 (2020).

10. W.A. Zakaria, T. Endaryanto, L.S.M. Indah, A. Mutolib, The economic role of cassava in farmers' household in Central Lampung Regency, Lampung Province, in Proceeding of E3S Web of Conferences 153, 03008 (2020).

11. H. Miftah, A. Syarbaini, SEPA. 10, 2 (2014).

12. Y.C. Siallagan, P.S. Asriani, A. Andani, Agrisep. 15, 2 (2016).

13. H. Saediman, A. Amini, R. Basiru, L. Nafiu, Journal of Sustainable Development. 8, 1 (2015).

14. L. Taslim, A. Rifin, S. Jahroh, Jurnal Agribisnis Indonesia. 8, 1 (2020).

15. E. Banowati, M.S. Mustofa, S.N. Rahmawati, Y. Sari, Komunitas. 12, 1 (2020). 
16. R.A. Far Far, A. Saleh, M. Hubeis, D. Susanto, IJPSAT. 21, 2 (2020).

17. A. Ishak, J. Firison, K. Dinata, S. Mutmaidah, Analisis keuntungan dan nilai tambah produk olahan ubi kayu skala rumah tangga di Kabupaten Bengkulu Tengah, in Prosiding Seminar Nasional Hasil Penelitian Aneka Kacang dan Umbi Tahun 2017, 26 Juli 2017, Malang, Indonesia (2017).

18. N.K. Denzin, Y.S. Lincoln, Introduction: the discipline and practice of qualitative research,in The SAGE Handbook of Qualitative Research, SAGE Publication, California (2005).

19. M.B. Miles, A.M. Huberman, J. Saldana, Qualitative Data Analysis: a Methods Source book, SAGE Publication, California (2014)

20. BPS Statistics of Bengkulu Tengah Regency, Kabupaten Bengkulu Tengah Dalam Angka, Kembang Seri (2020).

21. B. Unteawati, Fitriani, C. Fatih, Consumer's market analysis of products based on cassava, in Proceeding of IOP Conf. Series: Earth and Environmental Science 141, 012033 (2018).

22. H.L. Nainggolan, J. Aritonang, Agrium. 20, 3 (2017).

23. R.N. Kusumawati, K.K. Wardani, Suntoro, Caraka Tani. 36, 1 (2021).

24. Z. Rozaki, Agricultural Science. 8 (2020). 